\title{
INTERPRETASI KERUGIAN DALAM TINDAK PIDANA PEMALSUAN SURAT ${ }^{1}$
}

\author{
Oleh: \\ Wayan Santosa ${ }^{2}$
}

\begin{abstract}
Forgery is a crime that often occurs in the community. Letter forged, used for the benefit of the offender. Acceleration of information technology which is supported by the intellectual abilities cause crime perpetrators is increasingly easy to do. Article 263 of the Criminal Code specifies that one element of this criminal act is "may cause loss." The debate over the definition of loss is still often the case, the majority of law enforcement still considers that the loss of just about any material. In this study addressed two issues namely the forgery crime of criminal policy in positive law and evidence against losses in the crime of forgery. This research is normative legal research. Primary legal materials and secondary legal materials collected through the library research. Legal materials analysis was done by using descriptions, interpretation and argumentation techniques. Criminal Policy currently regulates the crime of counterfeiting in Book II of the Criminal Code in Article 263 of the Criminal Code. Criminal policy of forgery includes the step of judicial and applicable (law enforcement) policies. Proof against forgery intended to seek the truth and protect the interests of victims. "Loss" include the loss of material and immaterial (losses in the field of society, morality, honor, and so on).
\end{abstract}

Keywords: criminal policy, forgery, loss

\begin{abstract}
Abstrak
Pemalsuan adalah suatu kejahatan yang sering terjadi di masyarakat. Pemalsuan surat, dilakukan untuk kepentingan pelaku. Akselerasi teknologi informasi yang didukung dengan kemampuan intelektual pelaku menyebabkan tindak pidana ini semakin mudah dilakukan. Pasal 263 KUHP mengamanatkan bahwa salah satu unsur dari tindak pidana ini adalah "dapat menimbulkan kerugian." Perdebatan mengenai definisi kerugian masih sering terjadi, mayoritas penegak hukum masih memandang bahwa kerugian hanya menyangkut masalah material saja. Dalam penelitian ini akan dianalisis dua isu yakni kebijakan kriminal tindak pidana pemalsuan dalam hukum positif dan pembuktian kerugian dalam tindak pidana pemalsuan. Penelitian ini adalah penelitian yuridis normatif. Bahan hukum primer dan bahan hukum sekunder dikumpulkan melalui studi kepustakaan. Bahan hukum dianalisis dengan menggunakan teknik deskripsi, teknik interpretasi dan teknik argumentasi. Kebijakan kriminal tindak pidana pemalsuan dalam hukum positif diatur dalam Buku II KUHP yakni Pasal 263 KUHP. Kebijakan kriminal dari pemalsuan surat meliputi tahap yudisial dan tahap aplikatif (penegak

\footnotetext{
Artikel ini merupakan penelitian/karya ilmiah mahasiswa pada Program Studi Magister (S2) Ilmu Hukum Program Pascasarjana Universitas Udayana Jalan Diponogoro, 150 Blok A/23 Denpasar., email: ans_law_office@yahoo.co.id
}

2 Penulis pertama adalah mahasiswa magister ilmu hukum Universitas Udayana, Denpasar, Bali. Alamat
\end{abstract}


hukum). Pembuktian pemalsuan dilakukan untuk menegakkan kebenaran dan melindungi kepentingan korban. "Kerugian" meliputi kerugian materiil dan kerugian immaterial (kerugian di lapangan masyarakat, kesusilaan, kehormatan, dan sebagainya).

Kata Kunci: kebijakan kriminal, pemalsuan dan kerugian

\section{PENDAHULUAN}

\subsection{Latar Belakang}

Tindak pidana pidana pemalsuan surat (valschheid in geschrift) merupakan kejahatan yang cukup sering terjadi di masyarakat. Pemalsuan dilakukan dalam berbagai bentuk, mulai dari surat pada umumnya, pengakuanutang, akta, surat keterangan dokter, surat perjalanan dinas dan sebagainya. Pemalsuan surat tersebut tidak hanya menyangkut kepentingan antara individu, namun juga kepentingan suatu korporasi bahkan institusi pemerintahan. Pelaku pemalsuan surat, baik pembuat maupun yang menggunakan memiliki motif melakukan tindakan tersebut untuk melindungi kepentingannya atau menginginkan suatu hal terjadi sesuai dengan kehendaknya.

Akselerasi teknologi informasi yang didukung dengan kemampuan intelektual pelaku, mempermudah terjadinya tindak pidana ini. Mengenai tindakpidanaini,Pemalsuanmerupakan kejahatan yang mengakomodir sistem ketidakbenaran atau palsu atas sesuatu hal (obyek). Objek tersebut akan terlihat seolah-olah benar dari luar adanya, padahal telah bertentangan dengan kondisi yang sebenarnya. Tindak pidana pemalsuan diatur pada
Buku II KUHP yakni pada Pasal 263 KUHP. Dalam ketentuan tersebut dinyatakan

(1) Barang siapa membuat surat palsu atau memalsukan surat... ,diancamjika pemakaian tersebut dapat menimbulkan kerugian....

(2) Diancam...jika pemakaian surat itu dapat menimbulkan kerugian Ketentuan Pasal 263 KUHP merupakan upaya melindungi publica fides atau kepercayaan umum terhadap penerima surat. Rumusan tindak pidana pemalsuan sebagaimana yang diatur dalam Pasal 263 KUHP merumuskan secara tegas akibat tertentu dari dilakukannya perbuatan, dengan atau tanpa menyebutkan perbuatan tertentu itu dilakukan. ${ }^{3}$ Dalam ketentuan Pasal 263 KUHP, akibat yang dimaksud adalah "dapat menimbulkan kerugian." Menurut Pasal 263 KUHP, setiap orang dapat diancam dengan pidana jika perbuatannya tersebut menimbulkan potensi kerugian dikemudian hari.

Kerugian adalah unsur penting dari rumusan delik pemalsuan surat yang harus dibuktikan. Tanpa adanya unsur tersebut, maka perbuatan dianggap tidak terjadi. Frasa kerugian sendiri tidak dijelaskan di

Andi Hamzah, 2010, Asas-asas Hukum Pidana, Rineka Cipta, Jakarta, hlm. 107. 
dalam KUHP, sehingga diperlukan penafsiran atau interpretasi mengenai kerugian itu sendiri. Kekaburan norma mengenai kerugian akan berdampak pada optimalisasi penegak hukum. Penafsiran yang berbeda mengenai "kerugian sebagai kerugian material" atau mencakup pula "kerugian materiil dan kerugian immaterial" bertendensi menimbulkan standar ganda dalam penegakan hukum. Kerugian memang lebih diidentikkan pada lapangan hukum perdata, padahal dalam hukum pidana kerugian seringkali menjadi suatu unsur pasal yang menimbulkan akibat hukum, oleh sebab itu sangat menarik untuk membahas penelitian yang berjudul "Interpretasi Kerugian dalam Tindak Pidana Pemalsuan Surat."

\subsection{Perumusan Masalah}

Berdasarkan uraian latar berlakang yang telah dideskripsikan sebelumnya, maka permasalahanpermasalahan yang akan dibahas dalam penelitian ini meliputi:

1. Bagaimanakah kebijakan

kriminaltindakpidanapemalsuan surat dalam hukum positif?

2. Bagaimanakah pembuktian unsur kerugian dalam tindak pidana pemalsuan surat?

\subsection{Tujuan Penelitian}

Tujuan penulisan dalam penelitian inimeliputitujuan umum dan tujuan khusus yang dapat dijabarkan sebagai berikut: a. Tujuan Umum

Tujuan umum dari penelitian ini adalah untuk menganalisis dan menemukan interpretasi kerugian dalam tindak pidana pemalsuan surat. Penelitian ini sangat bermanfaat untuk pengembangan hukum pidana.

b. Tujuan Khusus

Tujuan khusus dari penelitian ini adalah sebagai berikut:

1) Untuk menganalisis kebijakan kriminaltindakpidanapemalsuan surat dalam hukum positif.

2) Untuk menganalisis pembuktian unsur kerugian dalam tindak pidana pemalsuan surat.

\section{METODE PENELITIAN}

2.1. Jenis Penelitian

Penelitian ini merupakan penelitian yuridis normatif. Sifat penelitian normatif merujuk pada penelitian dengan cara meneliti bahanbahan hukum. ${ }^{4}$ Penelitian ini dilakukan terhadap kekaburan norma mengenai unsur kerugian dalam tindak pidana pemalsuan surat sebagaimana yang diatur dalam Pasal 263 KUHP.

2.2. Jenis Pendekatan

Jenis pendekatan yang digunakan dalam menganalisis penelitian ini adalah dengan pendekatan perundangundangan (the statute approach), pendekatan analisis konsep hukum (analitical and conseptual approach) dan dengan pendekatan frasa (words

Soekanto, Soerjono, \& Mamudji, Sri, 2009, Penelitian Hukum Normatif, RajaGrafindo Persada, Jakarta, hlm. 1213 . 
and phrase approach). Pendekatan perundang-undangan (the statute approach) yakni dengan pendekatan melaluiperaturanperundang-undangan yang terkait dengan permasalahan yang dibahas seperti KUHP dan beberapa putusan pengadilan. Pendekatan analisis konsep hukum (analitical and conseptual approach) yakni dengan menggunakan konsep hukum seperti tindak pidana dan pemalsuan surat. Pendekatan frasa (words and phrase approach) dimana frasa yang dianalisis adalah unsur kerugian sebagaimana dimaksud dalam Pasal 263 KUHP.

\subsection{Sumber Bahan Hukum}

Bahan hukum yang digunakan dalam peelitian ini adalah bahan hukum primer yakni bahan hukum yang mengikat seperti KUHP dan putusan pengadilan serta bahan hukum sekunder yang menjelaskan bahan hukum primer, yang meliputi literaturliteratur mengenai hukum pidana.

\section{d. Teknik Pengumpulan Bahan Hukum}

Bahan hukum dikumpulkan melaui studi kepustakaan. Bahan hukumyang telah dikumpulkan melalui studi kepustakaan tersebut, dicatat dengan sistem kartu dan digunakan sebagai referensi dalam penelitian ini. Daftar referensi dituangkan dalam catatan kaki pada akhir pendapat yang digunakan. Pada bagian akhir penelitian tersebut, referensi yang digunakan ditulis pada daftar pustaka e. Teknis Analisis Bahan Hukum
Analisis bahan hukum dilakukan dengan teknik deskripsi, yaitu menggambarkan posisi dari proposisi-proposisi (dalil) hukum mengenai kerugian dalam tindak pidana pemalsuan. Teknik interpretasi juga digunakan dalam menganalisis kekaburan norma mengenai frasa kerugian dalam tindak pidana pemalsuan. Jenis interpretasi hukum yang digunakan adalah interpretasi sistematis yang mengaitkan dengan peraturan maupun putusan pengadilan yang ada. Analisis tersebut kemudian diperkuat dengan teknik argumentasi, yaitu alasan-alasan peneliti terhadap penilaian yang diberikan terhadap frasa kerugian dalam bahan hukum primer maupun bahan hukum sekunder.

\section{HASIL DAN PEMBAHASAN}

3.1. Kebijakan Kriminal Tindak Pidana Pemalsuan Surat dalam Hukum Positif

Kebijakan kriminal

(criminal policy) adalah kebijakan penanggulangan terhadap suatu kejahatan dengan menggunakan sarana hukum pidana. Sarana hukum pidana yang dimaksud meliputi tahap kebijakan yudikatif atau aplikatif (penegakan hukum pidana secara in concreto). Penanggulangan kejahatan melalui kebijakan kriminal wajib memperhatikan dan mengarah pada tercapainya tujuan dari kebijakan sosial. Kebijakan sosial yang dimaksud meliputi 'social welfare' atau kesejahteraan sosial dan "social 
defense' atau pertahanan sosial. ${ }^{5}$ Kebijakan kriminal melalui tahap legislatif dapat dilihat dari pengaturan tindak pidana pemalsuan surat dalam KUHP. Tindak pidana pemalsuan surat ini diatur dalam Pasal 263-276 KUHP.

Uraian terhadap tindak pidana pemalsuan surat secara umum dapat dilihat pada Pasal 263 ayat (1) KUHP. Padaketentuan tersebut dapat diketahui unsur-unsurnya sebagai berikut:
a. Barang siapa;
b. Membuat secara palsu atau memalsukan surat;
c. Surattersebutdapatmenimbulkan suatu hak, suatu perikatan atau suatu pembebasan utang atau;
d. Suatu surat yang dimaksud untuk membuktikan suatu kenyataan;
e. Dapat menimbulkan suatu kerugian.

Ketentuan Pasal 263 ayat (1) KUHP merumuskan dua perbuatan yakni membuat surat palsu dan memalsukan surat. Kedua perbuatan tersebut pada prinsipnya memiliki perbedaan. Perbuatan membuat surat palsuberarti sebelumnya memang tidak ada surat, kemudian pelaku membuat surat yang sebagian atau seluruhnya bertentangan dengan kebenaran, yang mana hasil perbuatan tersebut akan digunakan untuk kepentingannya. Memalsukan surat berarti sebelumnya

\footnotetext{
Barda Nawawi Arief, 2008, Masalah Penegakan Hukum dan Kebijakan Hukum Pidana dalam Penanggulangan Kejahatan, Kencana Prenada Media Group, Jakarta, hlm. 77.
}

sudah ada surat, namun surat tersebut diubah untuk kepentingan pelaku, baik seluruhnya atau sebagian. Pemalsuan surat termasuk pula pemalsuan tanda tangan dan pembuat surat sekalipun pemalsuan tanda tangan tersebut atas perintah yang berkepentingan.

Surat adalah segala tulisan baik yang dibuat dalam bentuk tulisan tangan, diketik, maupun dicetak dan dalam perkembangannya termasuk surat elektronik. Berdasarkan rumusan Pasal 263 ayat (1) KUHP, tidak semua pemalsuan surat dapat dipidana. Pemalsuan surat dapat dipidana apabila:

a. Surattersebutdapatmenimbulkan suatu hak, suatu perikatan atau suatu pembebasan utang atau;

b. Suatu surat yang dimaksud untuk membuktikan suatu kenyataan atau kejadian tertentu.

Pemalsuan surat sebagaimana dalamYurisprudensiMahkamahAgung membenarkan putusan Pengadilan Negeri Cirebon No. 12/1972 B, 5 Juli 1972. Dalam yurispudensi tersebut dinyatakan bahwa pemalsuan surat termasuk mengubah surat asli baik isi surat atau tanggal surat maupun tanda tangan penulis surat dimana surat tersebut menjadi bertentangan dengan kebenaran. Tindakan tersebut dilakukan dengan maksud tertentu, seperti untuk membuktikan suatu perkara. Dalam pembuktian suatu perkara, surat memiliki kedudukan yang penting sebab berdasarkan Pasal 184 ayat (1) KUHAP, surat merupakan 
alat bukti yang sah selain, keterangan saksi, keterangan ahli, petunjuk, dan keterangan terdakwa.

Dalam Pasal 263 ayat (2) KUHP, pemidanaan dilakukan terhadap pelaku yang menggunakan surat palsu. Mengenai tindak pidana pemalsuan surat ini, Topo Santoso menyatakan bahwa perbuatan pemalsuan dapat dihukum ketika ada niat dari pelaku. Pelaku disini harus mempunyai niat atau maksud untuk mempergunakan suatu barang yang kondisinya tidak benardengan menggambarkan keadaan barang tersebut itu seolah-olah asli seusia dengan niatan pelaku sehingga orang lain percaya terhadap apa yang digambarkan tersebut. Unsur niat atau maksud tidak perlu diikuti dengan unsur menguntungkan diri sendiri atau orang lain (hal ini berbeda dengan jenis perbuatan penipuan), namun perbuatan tersebut harus menimbulkan suatu keadaan berupa bahaya umum yang khususnya dalam pemalsuan tulisan atau surat dan sebagainya dirumuskan dengan unsur "dapat menimbulkan kerugian" akibat dari tulisan atau surat tersebut.

Pemalsuan surat adalah berupa kejahatan yang di dalam mengandung unsur keadaan ketidakbenaran atau palsu atas sesuatu (objek), yang sesuatunya itu tampak dari luar seolah-olah terlihat benar, padahal sesungguhnya bertentangan dengan yang sebenarnya. Perbuatan memalsukan surat tentunya dilakukan dengan memenuhi unsur kesengajaan, karena tindakan ini dilakukan melalui upaya sadar dari si pembuat/ pengguna surat itu sendiri yang digunakan untuk kepentingannya. Kepentingan disini meliputi kepentingan untuk menimbulkan sesuatu hak tertentu yang diinginkan, menciptakan suatu perikatan atau pembebasan hutang, atau yang dimaksudkan untuk digunakan sebagai bukti. Pemidanaan terhadap pelaku mencakup bagi subjek hukum yang membuat, subjek hukum yang menggunakan atau menyuruh orang lain menggunakan. Berdasarkan Yurisprudensi Mahkamah Agung No. 40/Kr/1973, 5 Juni 1975, pengisian blangko kuitansi dipandang tidak mempunyai unsur melawan hukum, apabila pengisian tersebut tidak bertentangan dengan maksud dari yang menandatangani. Supremasi hukum sangat didambakan oleh masyarakat. dalam kasus pemalsuan surat. ${ }^{6}$

Kebijakan kriminal terhadap pemalsuan surat juga meliputi kebijakan aplikatif atau penegakan hukum. Penegakan hukum dilakukan oleh masing-masing komponen peradilan pidana. Penegakan hukum didahului dengan tindakan penyidikan yang bertujuan untuk mengumpulkan barang bukti dan menemukan tersangkanya. Setelah penyidikan selesai dilakukan, maka

\footnotetext{
Bramanda Wiratama, Frendy Nur Pratama dan Ismail Eka Syahrial, Peran Serta Proses Identifikasi Laboratorium Forensik dalam Penyelidikan Kasus Pemalsuan Surat dan Tanda Tangan, Jurnal GEMA, THN XXVII/50/ Pebruari - Juli 2015, UNS, Surakarta, hlm. 1862.
} 
tahap berikutnya adalah penuntutan dan dilanjutkan dengan persidangan. Persidangan tindak pidana pemalsuan dilakukan secara terbuka dan dibuka untuk umum. Anthon F. Susanto mengatakan bahwa pembuatan putusan bukanlah pekerjaan mudah bagi hakim. Unsur keadilan, kepastian hukum dan kemanfaatan harus dipertimbangkan sehingga putusan yang dibuat oleh hakim dapat memenuhi harapan pencari keadilan. $^{7}$

Kesulitan dalam proses hukum pemalsuan biasanya terletak pada pembuktian unsur kerugian. Sebagian penegak hukum masih memandang bahwa kerugian hanya terbatas pada kerugian materiil saja, sedangkan kerugian immaterial tidak dipandang sebagai kerugian karena sulit untuk ditentukan. Kebijakan aplikatif dalam pembuktian adanya tindak pidana pemalsuan bertujuan untuk menegakkan keadilan secara keseluruhan mencakup kepentingan korban dan pelaku.

\subsection{Pembuktian Unsur Kerugian dalam Tindak Pidana Pemalsuan Surat}

Pembuktian adalah proses yang penting untuk mencari kebenaran materiil dalam perkara pidana. Pembuktian yang dilakukan di muka sidang pengadilan memberikan

\footnotetext{
Anthon F. Susanto, Problematika Nalar dan Kekuasaan; Kajian Putusan MA Nomor 36P/Hum/2011, Jurnal Yudisial, Vol. 5, No. 2 Tahun 2012, Edisi Agustus 2012, Komisi Yudisial Republik Indonesia, Jakarta, hlm. 118.
}

kepastian suatu peristiwa tertentu. ${ }^{8}$ Pembuktian akan menentukan benar atau salahnya terdakwa, yang artinya bahwa tahap pembuktian menjadi acara yang menentukan nasib terdakwa dikemudian hari. Setiap unsur yang didakwakan oleh jaksa penuntut umum harus dibuktikan. Teknik pembuktian harus dilaksanakan dengan baik oleh penuntut umum, hakim, dan penasihat hukum, jika tidak maka terdakwa dapat bebas dari hukuman. ${ }^{9}$

Fakta-fakta hukum yang terungkap di persidangan harus dirumuskan secara cermat, jelas dan lengkap untuk memenuhi unsur-unsur tindak pidana sebagaimana yang didakwakan. Fakta hukum disusun untuk memenuhi unsur-unsur pasal sebagaimana yang didakwakan. ${ }^{10}$ Unsur dapat menimbulkan kerugian merupakan salah satu unsur yang harus dibuktikan dalam pembuktikan

\footnotetext{
N. Ike Kusmiati, Kekuatan Pembuktian Surat Berita Acara Pemeriksaan Tersangka yang Dijadikan Alat Bukti, Jurnal Yudisial, Vol. IV, No. 1 Tahun 2011, Edisi April 2011, Komisi Yudisial Republik Indonesia, Jakarta, hlm. 63.

Marwan Mas, Penguatan Argumentasi FaktaFakta Persidangan dan Teori Hukum Dalam Putusan Hakim, Jurnal Yudisial, Vol. 5 No. 3 Tahun 2012, Edisi Desember 2012, Komisi Yudisial Republik Indonesia, Jakarta, hlm. 290.

10 Muhandas Ulimen, Analisis Terhadap Pelaksanan Pununtutan serta Tuntutan Pidana Perkara Pemalsuan Uang Berdasarkan Surat Edaran Jaksa Agung Nomor SE-013/ A/JA/12/2011 Tentang Pedoman Tuntutan Pidana Perkara Tindak Pidana Umum Dalam Rangka Mewujudkan Sistem Peradilan Pidana, Jurnal Pasca Sarjana, Vol. 5, No. 1 Tahun 2015, Edisi Januari-Juni 2015, UNS, Surakarta, hlm. 43.
} 
terhadap tindak pidana pemalsuan surat. Frasa "dapat menimbulkan kerugian" adalah akibat dari perbuatan. Rumusan delik tersebut menekankan pada akibat dari adanya perbuatan memalsu, baik dalam membuat ataupun menggunakan surat palsu.

Sebagai unsur penting, maka unsur kerugian harus dibuktikan. Kerugian dalam tindak pidana pemalsuan surat dirumuskan dengan kata "dapat menimbulkan kerugian." Akibat dari perbuatan tersebut tidak perlu kerugian yang betul-betul ada, baru kemungkinan akan adanya kerugian saja sudah dipandang cukup. Perumusan yang lebih luas yang mencakup potensi kerugian untuk dapat terwujudnya delik pemalsuan sebagaimana yang diatur menurut Pasal 263 ayat (2) KUHP merupakan upaya pembuat undang-undang dalam mewujudkan hukum yang responsif. Hukum responsif selalu bercirikan kompetensi kognitif, dimana kompetensi tersebut didasarkan pada moralitas sipil yakni morality of cooperation. ${ }^{11}$ Tindak pidana pemalsuan bukan hanya pelanggaran terhadap norma hukum, melainkan juga bertentangan dengan moralitas. Ketidakbenaran yang dibuat dengan sengaja menjadi ciri betapa moralitas telah dilanggar oleh pembuatnya.

Unsur dapat menimbulkan kerugian menjadi unsur yang seringkali diperdebatkan oleh penegak hukum dalam merumuskan tindak

Ali Zaidin, 2015, Menuju Pembaruan Hukum Pidana, Sinar Grafika, Jakarta, hlm. 82. pidana mulai sejak tahap penyidikan hingga pada tahap persidangan. Kerugian seringkali hanya dipandang sebagai kerugian dalam bentuk materiil, namun tidak mencakup kerugian immaterial. Akibatnya, jika pelapor tidak mengalami kerugian yang dapat dihitung dengan nominal angka, maka laporannya tidak dapat diproses. Pandangan penegak hukum yang demikian memang wajar adanya mengingatdalam BukuIKUHP tentang aturan umum sendiri tidak memuat mengenai definisi kerugian. Unsur kerugian tersebar di beberapa pasal dalam KUHP, sebagian diantaranya menyebutkan dengan frasa "nilai kerugian." Berdasarkan hal tersebut, maka wajarlah ketika penegak hukum lebih mengartikan kerugian dalam bentuk kerugian materiil saja.

Dalam studi kejahatan, seringkali masalah kerugian materiil dibahas sebagai akibat dari terjadinya suatu kejahatan. Moh. Hatta, dalam bukunya yang berjudul "Beberapa Masalah Penegakan Hukum Pidana Umum dan Pidana Khusus" menyebutkan bahwa kerugian dapat diukur dengan jumlah uang yang diderita korban. Selain kerugian langsung, korban juga mengalami kerugian tidak langsung, yakni mengeluarkan biayabiaya selama proses peradilan pidana berlangsung sejak di kepolisian, kejaksaan, pengadilan dan lembaga pemasyarakatan. ${ }^{12}$

12 Moh. Hatta, 2009, Beberapa Masalah Penegakan Hukum Pidana Umum dan Pidana Khusus, Liberty, Yogyakarta, hlm. 35. 
Kerugian tersebut merupakan materiil, lebih luas daripada itu, korban maupun masyarakat secara umum juga mengalami kerugian berupa ancaman ketakutan, hilangnya rasa aman dan ketidakpercayaan terhadap penegak hukum.

Terkait dengan tindak pidana pemalsuan surat pada umumnya sebagaimana yang diatur dalam Pasal 263 KUHP, kerugian dalam frasa ini tidak saja hanya meliputi kerugian materiil, namun juga mencakup kerugian di lapangan masyarakat, kesusilaan, kehormatan, dan sebagainya yang sifatnya immateriil. Beberapa hal yang harus diperhatikan dalammenganalisis mengenai kerugian adalah sebagai berikut:

a. DalamketentuanPasal263KUHP tidak disyaratkan timbulnya kerugian melainkan hanya potensi yang memungkinkan terjadinya kerugian (H.R, 22 April 1907, W. 8536, 1 Des. 1941, 1942 No. 241).

b. Untuk dapat dipidana, terdakwa tidak perlu dapat membayangkan kemungkinantimbulnyakerugian tersebut (H.R. 8 Juni 1897, W. 6981, 15 Jan, W. 9288).

c. Kerugian itu harus dapat ditimbulkan dari adanya penggunaan surat sebagaimana yang diinginkan oleh si pelaku. Pemalsuan tersebut tidak cukup jika hanya menyebabkan kepercayaan kepada pegawai itu menjadi berkurang dan menyebabkan nama baik dari kantor gemeente menjadi tercemar (H.R. 17 Jan. 1898, W. 7075).

d. Kemungkinan akan timbulnya kerugian dari penggunaan surat yang dipalsukan itu adalah sifat objektif dari surat itu sendiri. Kerugian itu tidaklah perlu nyata (H.R. 29 Jan. 1912, W. 9288; 29 Nop. 1943, 1944 No. 142).

e. Kerugian itu bukanlah hanya kerugianmaterial,jugadipandang sebagai kerugian apabila penggunaan surat palsu itu dapat mempersulit pemeriksaan polisi maka kepentingan umum yang telah dirugikan (H.R. 14 Okt. 1940, 1941, No. 42).

f. Memungkinkan timbulnya kerugian itu dapat terjadi karena:

- Mempersulit suatu kontrol atau pengawasan (H.R. 14 Des. 1936, 1937 No. 392).

- Ditutupinya suatu tindak pidana penggelapan yang telah dilakukan (H.R. 17 Pebr. 1936, 1936 No. 471)

- Manipulasi harga berupa pencantuman harga beli yang tidak sebenarnya di dalam akta jual beli sehingga pembayaran biaya registrasi menjadi lebih rendah daripada semestinya (H.R. 14 Maret 1898, W. 7098, 11 April 1899, W. 7268). 
- Terpaksa diselesaikan melalui suatu proses (H.R. 2 Jan. 1939 No. 577).

Dalam yurisprudensi Mahkamah Agung 29 Mei 1965 No. 10 K/Kr/ 1965 dinyatakan bahwa kemungkinan kerugian yang ditimbulkan dari adanya pemalsuan surat berdasarkan Pasal 263 KUHP tidak harus berupa kerugian materiil.Kerugianyang dimaksuddapat berupa kerugian terhadap kepentingan masyarakat yakni penggunaan surat yang dipalsukan yang berakibat pada sulitnya penyidikan dalam suatu perkara. Kerugian immaterial telah dirumuskan oleh beberapa putusan dalam perkara perdata. Pada Putusan Nomor : 89 PK/Pdt/2010, kerugian immaterial yang diputuskan berupa telah kehilangan waktu, tenaga dan pikiran serta beban moril dalam menghadapi ketidakpastian akan pelaksanaan perjanjian, rusaknya nama baik atau goodwill suatu perusahaan dimata konsumen, mitra bisnis dan juga dimata para karyawan perusahaan itu sendiri. Ketentuan dalam Pasal 263 KUHP merupakan delik biasa, oleh sebab itu proses hukum dapat dilakukan dengan adanya laporan, tanpa memerlukan pengaduan dari pihak yang dirugikan.

\section{PENUTUP}

\subsection{Simpulan}

1. Kebijakan kriminal tindak pidana pemalsuan surat dalam hukum positif meliputi tahap kebijakan yudikatif atau aplikatif. Pada tahap kebijakan yudikatif, tindak pidana ini diatur dalam Pasal 263 KUHP. Delik tersebut menekankan pada rumusan akibat yakni dapat menimbulkan kerugian. Tahap kebijakan aplikatif dilakukan dengan penegakan hukum terhadap tindak pidana ini. Penegakan hukum dimulai sejak tahap penyidikan hingga pembinaan di lembaga pemasyarakatan.

2. Pembuktian unsur kerugian dalam tindak pidana pemalsuan surat dilakukan untuk mencari kebenaran materiil. Dalam KUHP tidak dijelaskan mengenai pengertian kerugian. Pengertian kerugian dapat ditelusuri melalui yurisprudensi doktrin ahli hukum yang merumuskan bahwa kerugian meliputi kerugian materiil dan immaterial yang mencakup kerugian di lapangan masyarakat, kesusilaan, kehormatan, dan sebagainya.

\section{Saran}

1. Penegak hukum, terutama penyidik sebagai pintu utama dalam penegakan hukum pidana hendaknya menginterpretasikan kerugian sebagai kerugian materiil dan immaterial sebagaimana yang tercantum dalam yurispudensi dan pendapat ahli hukum pidana.

2. Akademisi hukum hendaknya meneliti frasa-frasa dalam hukum pidana yang belum 
diatur dalam undang-undang dan mempublikasikan hasil penelitian tersebut agar dapat digunakan sebagai referensi bagi ilmuwan dan praktisi hukum pidana.

\section{DAFTAR PUSTAKA}

\section{Buku}

Ali Zaidin, 2015, Mепијu Pembaruan Hukum Pidana, Sinar Grafika, Jakarta.

Andi Hamzah, 2010, Asas-asas Hukum Pidana, Rineka Cipta, Jakarta.

Barda Nawawi Arief, 2008, Masalah Penegakan Hukum dan Kebijakan Hukum Pidana dalam Penanggulangan Kejahatan, Kencana Prenada Media Group, Jakarta.

Hatta, Moh., 2009, Beberapa Masalah Penegakan Hukum Pidana Umum dan Pidana Khusus, Liberty, Yogyakarta.

Soekanto, Soerjono, \& Mamudji, Sri, 2009, Penelitian Hukum Normatif, RajaGrafindo Persada, Jakarta.

\section{ARTIKEL ILMIAH}

Anthon F. Susanto, Problematika Nalar dan Kekuasaan; Kajian Putusan MA Nomor 36P/ Hum/2011, Jurnal Yudisial, Vol. 5, No. 2 Tahun 2012, Edisi Agustus 2012, Komisi Yudisial Republik Indonesia, Jakarta.

Bramanda Wiratama, Frendy Nur Pratama dan Ismail Eka Syahrial, Peran Serta Proses Identifikasi
Laboratorium Forensik dalam Penyelidikan Kasus Pemalsuan Surat dan Tanda Tangan, Jurnal GEMA, THN XXVII/50/ Pebruari - Juli 2015, UNS, Surakarta.

IkeKusmiati,N.,KekuatanPembuktian Surat Berita Acara Pemeriksaan Tersangka yang Dijadikan Alat Bukti, Jurnal Yudisial, Vol. IV, No. 1 Tahun 2011, Edisi April 2011, Komisi Yudisial Republik Indonesia, Jakarta.

Marwan Mas, Penguatan Argumentasi Fakta-Fakta Persidangan dan Teori Hukum Dalam Putusan Hakim, Jurnal Yudisial, Vol. 5 No. 3 Tahun 2012, Edisi Desember 2012, Komisi Yudisial Republik Indonesia, Jakarta.

Ulimen, Muhandas, Analisis Terhadap Pelaksanan Pununtutan serta Tuntutan Pidana Perkara Pemalsuan Uang Berdasarkan Surat Edaran Jaksa Agung Nomor SE-013/A/JA/12/2011 Tentang Pedoman Tuntutan Pidana Perkara Tindak Pidana Umum Dalam Rangka Mewujudkan Sistem Peradilan Pidana, Jurnal Pasca Sarjana, Vol. 5, No. 1 Tahun 2015, Edisi Januari-Juni 2015, UNS, Surakarta.

\section{PERATURAN PERUNDANG UNDANGAN}

Kitab Undang-undang Hukum Pidana. Kitab Undang-undang Hukum Acara Pidana. 